\title{
Archæological Excavations in Iraq*
}

$\mathrm{I}^{\mathrm{N}}$ the season 1932-33, which is covered by the third preliminary report of the director, Dr. Henri Frankfort, the Oriental Institute of Chicago was responsible for three major investigations in Iraqat Tell Asmar, Khafaje and Khorsabad, and to the last of these were subjoined two minor investigations at Tepe Shenshi and Jerwan, to which the attention of the field staff was turned when, towards the close of the season, the weather precluded further activity in southern Iraq.

The results of the season 1932-33 fully confirmed the impression which had been formed in the previous season that the site at Tell Asmar, the ancient Eshnunna, is likely to prove one of the most important in the south. Not indeed that it is probable that it will eclipse Ur in the richness of the finds or in the imposing character of the buildings; but, on the other hand, the evidence which it has already afforded indicates that it will be of first-rate significance in the elucidation of a number of problems of Mesopotamian prehistory.

Of these problems one of the most vigorously debated has been the dating of the Royai Tombs at Ur. According to the interpretation of the evidence from Tell Asmar by Dr. Henri Frankfort, this must now be placed much lower than has been proposed by Dr. L. Woolley, though it does not demand the extreme reduction favoured by some authorities. At the time of writing this third report, Dr. Frankfort was not yet in a position to formulate a final judgment; but he was able to show that the evidence pointed to a contemporaneity of the tombs at Ur with the fifth stratum of his series at Tell Asmar, that is, the stratum preceding the Sargonid period. A possible date would, therefore, be c. 2700 B.c. as against the c. 3500 B.c. which commended itself to Dr. Woolley.

The conditions of excavation at Tell Asmar were peculiarly favourable to determining chronological questions; they were such as to afford a basis of greater certainty than could be obtained from the excavation of a cemetery. The northern hills of Tell Asmar had not been inhabited in the Larsa period, or later, while in the extreme north a large building and a group of private houses south of it had been partially uncovered. It was, therefore, possible to extend the excavations over a wide area and to avoid generalisation on a single example. At the same time, stratification could be determined with certainty. This latter factor is of special importance, as it was found, in working out the plan of the city, that stratification was not a mere matter of determining absolute levels. Constant rebuilding of structures fallen into disrepair over a long period of time had been responsible for differences in level, sometimes of a metre or more, between buildings of the same cultural epoch. A further cause of a possible confusion was the survival of archaic features into periods to which they did not belong. This was found to be due to the adaptation of the ruins of older structures as supports for the new.

In two respects in particular, the season's excava-

* Iraq Excavations of the Oriental Institute, 1932-33: Third Preliminary Report of the Iraq Expedition. By Henri Frankfort (The Oriental Institute of the University of Chicago: Oriental (The Orie Communications, No. 17.) Pp. ix +92. (Chicago: UniverInstitute Communications, Nond : Cambridge University Press, 1934.) 78. net. tions at Tell Asmar are of outstanding importance for the cultural history of early Mesopotamia-the view they afford of the conditions of life of the private citizen ; and, secondly, in the new knowledge they have yielded of early phases of religious cult and belief.

The conditions of life among the ordinary citizens are revealed in the remains of the large number of private dwellings which have been uncovered. From these the excavators have been able to determine or infer the lines of a fairly complete plan of the city, and at the same time to reconstruct the typical dwelling of the Sumero-Akkadian culture. So far as the private dwelling is concerned, it is noted that there appears to be no marked break in occupation with the incoming of the Sargonid era, and it continued uninterrupted down to the period of the Third Dynasty of Ur ; but in the area of the large building, which Dr. Frankfort considers sufficiently extensive and complex to justify the denomination 'palace', there is a period of apparent abandonment represented by about a metre of rubbish which intervenes at the close of the Sargonid period.

The reconstruction of the Akkadian dwellingplaces emphasises several interesting features in the arrangement and relation of the various chambers. They differ from buildings at Ur in the absence of the open courtyard. Two notable additions are made to knowledge of the architectural accomplishments of this early period in the form of a window, lighting a store-room by means of a terra-cotta grille, and the use of the arch in communicating doorways. In both instances this is the earliest known example in Mesopotamia. In the 'palace' building by far the most remarkable structural feature is the sanitary system, in which, however, Dr. Frankfort notes, in the greater number of instances, the rooms are not congruous with this use.

The excavation of the 'Temple of Abu', the temple of the god of fertility, has provided some remarkable material bearing upon the early form of religious belief in Mesopotamia, of which, however, the full significance is to be completely appreciated only when it is brought into relation with the cult material obtained from the private dwelling houses. The unity of 'public' and 'private' cult is striking. The salient fact which emerges is that this SumeroAkkadian religion centres around one deity; although, it is true, at this time the existence both of a great mother goddess and of a sun-god was recognised. The god of fertility, however, is the central figure of the pantheon. He personifies the generative forces of Nature and is closely associated with the crops and flocks and herds. It follows that the various names of deities, Ninurta, Ningirsu, Abu Dumuzi (Tammuz) and the like are in reality but epithets referring to different aspects of this early deity, and tradition may have decided which aspect was to prevail in any given locality. Hence also it is clear that this fertility god was a Sumerian and not a Semitic deity. Not only was he the generative force in Nature, manifest in the fertility of the soil and the flocks, but also he lived in the netherworld, often assumed the shape of a serpent, was exposed to dangerous encounters, and vanquished monsters. From this last manifestation Heracles, it has been shown, stands in direct line of descent. The 
consummation of his marriage with a goddess was an essential part of the annual ritual. This ceremony was well known from other sources, but Tell Asmar has afforded on a seal the only known representation of the divine nuptials in early Mesopotamia.

Among a hoard of copper objects enclosed in a pot was a bronze open-work dagger-handle in which was wedged a fragment of the original blade. This has been examined by Dr. C. H. Desch, who pronounces it to be iron of telluric origin. As it belongs to the 28th century B.C., it is by many hundreds of years the earliest example known. The same applies to a fragment of clear glass which has been examined by Mr. Horace C. Beck, who points out how surprising it is to find in Mesopotamia clear glass dating from 2700 B.c., since in Egypt, although opaque glass was known in the second millennium B.c., clear glass was not introduced before Roman times.

It has been possible to touch only on the more striking points in Dr. Frankfort's report, while the excavations at Khafaje and Khorsabad must be passed over, notwithstanding their interest and importance. The excavations of the Oriental Institute closed for the season in 1933 at a point which promised much in the following season. This expectation was not disappointed and the further reports of the director are awaited with interest.

\section{Three-Colour, One-Exposure Camera}

$\mathrm{T}$ HE customary method of making a set of colourseparation negatives for colour photography is by successive exposures on separate plates through the appropriate colour filters. Usually three negatives are required. This method fails for snapshot exposures of moving objects. For many years inventors have attempted to devise three-colour cameras operating with a single exposure during which all three images are simultaneously recorded. Several of the optical devices which have been used to achieve this end were briefly described by Dr. D. A. Spencer in 1933 (Photographic J., 74, 103; 1934) and a further method was described in 1934 (ibid., 74,244 ; 1934) by the late Mr. W. T. P. Cunningham.

One of the less difficult methods depends on the use of two inclined, semi-reflecting, plane mirrors. Light from the camera lens strikes the first mirror and a portion of it is deflected to form an image on one of the photographic plates placed behind its suitable colour filter; the remainder of the light goes on and meets the second mirror, which deflects a portion on to another plate, and the remainder goes on to the back of the camera where the third filter and plate are situated. One objection to this method is that reflection takes place at both surfaces of each mirror and, if the mirrors are thick, double images may be formed. This has led to the use of thin pellicle mirrors which are said to have been suggested by Geisler so long ago as 1910 (see Spencer, loc. cit) and have recently been made as commercial articles by Mr. H. O. Klein. It is said that other ways of avoiding double images with this general arrangement of semi-reflecting mirrors are also available.

The method has therefore led to considerable practical success and at present there are available two cameras which make use of it. These were both shown at the recent British Industries Fair. One is the Taylor-Hobson three-colour camera (Vivex system) and the other is the Klein tri-colour camera invented by Adrian B. Klein and manufactured by Messrs. Bellingham and Stanley, Itd. These cameras are said to work successfully to give exposures ranging from $1 / 25$ sec. to $1 / 10 \mathrm{sec}$. in winter sunshine. In quiries about these cameras should be addressed, in relation to the first to Messrs. Colour Photographs (British and Foreign), Ltd., Victoria Road, Willesden, N.W.I0, and in relation to the second to Messrs. Farquhar and Moloney, 15-16 Newman Street, London, W.1, or to Messrs. Bellingham and Stanley, Ltd., 71 Hornsey Rise, London, N.19.

\section{A Japanese Scientific Expedition to Manchoukuo*}

\begin{abstract}
7 HE Japanese have lost no time in examining the resources of the new 'independent' kingdom of Manchoukuo, and in October and November of 1934 were published in Tokyo the early sections of a report upon the first Japanese scientific expedition to the country, which carried out exploration work with the aid of motor transport and some aeroplane reconnaissance during the period June to October 1933. Under the leadership of the geologist, Prof. Shigeyasu Tokunaga, of Waseda University, thirteen scientific workers representing geography, botany, zoology and anthropology were dispatched from Japan, largely through the influence of Viscount Toki, Vice-Parliamentary Secretary of the War Office. Never before has a scientific expedition been dispatched abroad from Japan on so big a scale.

- Report of the First Scientiflc Expedition to Manchoukuo under the Leadership of Shigeyasu Tokunaga, June-October 1933. Section 1: Natural Science Research of the First Scientific Expedition to Manchoukuo. By Shigeyasu Tokunaga. Pp. iii $+76+69$ plates Section 4, Part 1: Plantæ Novæ Jeholenses, I. By Takenoshin Naka and Masae Kitagawa. Pp. iv $+71+20$ plates. Section 5, Part 1 The Fresh Water Fishes of Jehol. By Tamezo Mori. Pp. i $+61+21$ plates. (Tokyo : Waseda University, 1934.)
\end{abstract}

The reports now published are in Japanese with a very full transcript in English, which manages to express some of the enthusiasm with which the expedition has undertaken its task, regarded as important both on patriotic and scientific grounds. Before leaving Tokyo on July 22 the members of the expedition assembled in Tokyo in front of the 'Nijiu Bashi' (bridges at the entrance of the Palace) and worshipped at the entrance of the Palace; by July 30 they were in Hsin-king, the capital of Manchoukuo, and there they met again on October 12 "amidst the tear-prompting, enthusiastic welcome of the Government officials as well as plain people". On October 11 in the presence of Viscount Toki "the expedition drank to the happy completion of the scientific investigations at the risk of lives". During the intervening seventy days, some 5,000 kilometres had been covered in automobiles over trackless country; "the bottoms of the rivers are rather shallow [elsewhere described as "abdomendeep"], yet the quagmire-bed so deep. The treacherous rivers!" So far as possible they drove 